\title{
Open
}

\section{c-Ets1 inhibits the interaction of NF-kB and CREB, and downregulates IL-1 $\beta$-induced MUC5AC overproduction during airway inflammation}

\author{
KS Song ${ }^{1}$ J-H Yoon ${ }^{2,3}, \mathrm{KS} \mathrm{Kim}^{4}$ and DW Ahn ${ }^{1}$
}

Mucin hypersecretion is frequently observed in many inflammatory diseases of the human respiratory tract. As mucin hypersecretion refers to uncontrolled mucin expression and secretion during inflammation, studies examining the negative control mechanisms of mucin hypersecretion are vital in developing novel therapeutic medications. We hypothesized that the $c$-Ets1 induced by interleukin (IL)-1 $\beta$ would decrease MUC5AC overproduction by inhibiting the interaction of NF- $\kappa B$ with cAMP response element-binding protein (CREB) in vivo. Stimulation with IL-1 $\beta$ caused the direct binding of NF-KB and CREB to the MUC5AC promoter, thus increasing MUC5AC gene expression. However, IL-1 $\beta$-induced MUC5AC messenger RNA levels were surprizingly downregulated by C-Ets1 (located -938 to -930 ). Interestingly, C-Ets1 also suppressed IL-1 $\beta$-induced MUC5AC gene expression in vitro and in vivo by disrupting the interaction of NF- $\mathrm{KB}$ with CREB on the MUC5AC promoter. In addition, c-Ets1 also inhibited significant morphologic changes and inflammatory cell infiltration after IL-1 $\beta$ exposure in mouse lungs infected with either wild-type or shRNAc-Ets1. Moreover, reactive oxygen species produced by NOX4 increased c-Ets1 gene expression and MUC5AC gene expression in alveolar macrophages from bronchoalveolar lavage fluid. These results suggest a molecular paradigm for the establishment of a novel mechanism underlying the negative regulation of mucin overproduction, thus enhancing our understanding of airway inflammation.

\section{INTRODUCTION}

Understanding the mechanisms that regulate mucus hyperproduction and hypersecretion in respiratory diseases is critical for developing new therapeutic medications to use against inflammation. Although the importance of MUC5AC and MUC8 during airway inflammation has been emphasized in our previous studies, ${ }^{1-3}$ the negative regulatory mechanisms that can decrease their expressions in the airway remain unclear. Uncontrolled mucin hyperproduction and hypersecretion can increase morbidity and mortality by obstructing mucociliary clearance and air flow. ${ }^{4-6}$ Thus, clarification of the intracellular mechanism underlying the negative regulation of cytokine-induced MUC5AC overproduction could provide important clues toward understanding airway mucous hypersecretion.
c-E26 transformation-specific (Ets) 1 is a member of a family of transcription factors that have important roles in biological processes. ${ }^{7}$ To date, more than 25 mammalian Ets family members have been characterized and are known to control important biological processes including cellular proliferation, differentiation, lymphocyte development, and activation, and transformation via the recognition of a GCA core sequence in the promoter or enhancer of target genes, and mutual regulation of the pro- and anti-inflammatory $\mathrm{T}_{\mathrm{H}} 1$ response. ${ }^{8}$ The probable dual function of c-Ets1 in the regulation of cellular phenomena has been suggested by the finding that c-Ets1 might be essential for the initiation and progression of $\mathrm{T}_{\mathrm{H}}$ 1-cell-mediated macrophages. This activation occurs by controlling the expression of several inflammatory cytokines/chemokines. ${ }^{9}$ There are protein-protein interactions that are involved in every step of

\footnotetext{
${ }^{1}$ Department of Physiology, Kosin University College of Medicine, Busan, Korea. ${ }^{2}$ Department of Otorhinolaryngology, Yonsei University College of Medicine, Seoul, Korea. ${ }^{3}$ Research Center for Human Natural Defense System, Yonsei University College of Medicine, Seoul, Korea. ${ }^{4}$ Department of Otorhinolaryngology-Head and Neck Surgery, Chung-Ang University, Seoul, Korea. Correspondence: DW Ahn (dwahn@kosin.ac.kr) 
intracellular signaling, transcriptional transactivity regulation, and transcription factors turnover. ${ }^{10}$ Therefore, we examined the role of c-Ets1 in a negative regulatory mechanism facilitated by disrupting the protein-protein (or transcription factor-transcription factor) interaction on the MUC5AC promoter.

Reactive oxygen species (ROS) are induced by proinflammatory cytokines such as interleukins and tumor necrosis factor, during atherosclerosis. ${ }^{11}$ Superoxide anions are produced in vascular tissue by xanthine oxidases, cyclooxygenases, and $\mathrm{NADPH}$ oxidases (NOX). ${ }^{12} \mathrm{NAD}(\mathrm{P}) \mathrm{H}$ oxidases are the major sources of superoxide in vascular cells, and are essential in physiological responses and pathological states. The former includes cell growth, cell migration, and modification of the extracellular matrix, and the pathological states are associated with uncontrolled growth and inflammation, such as in atherosclerosis. ${ }^{13}$ Until now, seven homologs of gp91 phox (NADPH oxidase; NOX2), the core component of NOX, have been identified in various nonphagocytic cells, including NOX1, NOX3, NOX4, NOX5, DUOX1, and DUOX2. ${ }^{14}$ Of these, NOX4 is strongly expressed in endothelial cells. ${ }^{15}$ Ushio-Fukai ${ }^{16}$ showed that while ROS induces Ets-1 expression, the activated Ets-1 increases the expression of ROS-generating enzymes. The aims of this study were as follows: (1) characterize the function of c-Ets1 in interleukin (IL)-1 $\beta$-induced MUC5AC gene expression in vitro and in vivo; (2) identify the mechanism by which c-Ets1 inhibits IL- $1 \beta$-induced mucus overexpression; and (3) identify how ROS, produced by NADPH oxidase, influences the function of c-Ets- 1 in IL-1 $\beta$-induced MUC5AC overexpression.

\section{RESULTS}

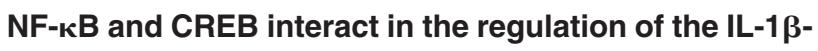
dependent MUC5AC gene expression in the human airway epithelial cells ( $\mathrm{NCl}-\mathrm{H} 292)$

To determine whether NF- $\kappa \mathrm{B}$ activation is involved in the nuclear signaling of IL-1 $\beta$-induced MUC5AC gene expression, we performed Western blotting with several phospho-specific antibodies. Alterations were seen in the phosphorylation status of $і \kappa B, N F-\kappa B$, and cAMP response element-binding protein (CREB) after IL-1 $\beta$ treatment, but no expression changes were observed for NF- $\kappa \mathrm{B}$, CREB, or CREB-binding protein (CBP) (Figure 1a). As a result, we hypothesized that the interaction of NF- $\kappa B$ with CREB may form a ternary complex with CBP and DNA to affect $M U C 5 A C$ gene expression in IL-1 $\beta$-induced signaling. To test our hypothesis, we performed an immunoprecipitation assay after the IL- $1 \beta$ treatment. CBP was able to bind to the NF- $\kappa B$ after IL- $1 \beta$ treatment (Figure 1b), resulting in the formation of CREB-CBP-NF- $\kappa B$ to induce physiological phenomena. Interestingly, $\mathrm{CREB}$ was unable to bind to the NF- $\kappa \mathrm{B}$ regardless of IL- $1 \beta$ treatment (Figure $\mathbf{1 b}$, top panel), whereas activated CREB bound to NF- $\kappa B$ in a time-dependent manner (Figure $\mathbf{1 b}$, bottom panel). Moreover, we used small interfering RNA (siRNA) constructs of CREB and NF- $\kappa B$ to examine whether the correlation between the physical interactions of CREB with NF- $\kappa B$ increases the transcriptional activity of the MUC5AC gene. We found that inhibition of either CREB or NF- $\kappa B$ suppressed IL-1 $\beta$-induced MUC5AC gene expression (Figure 1c).
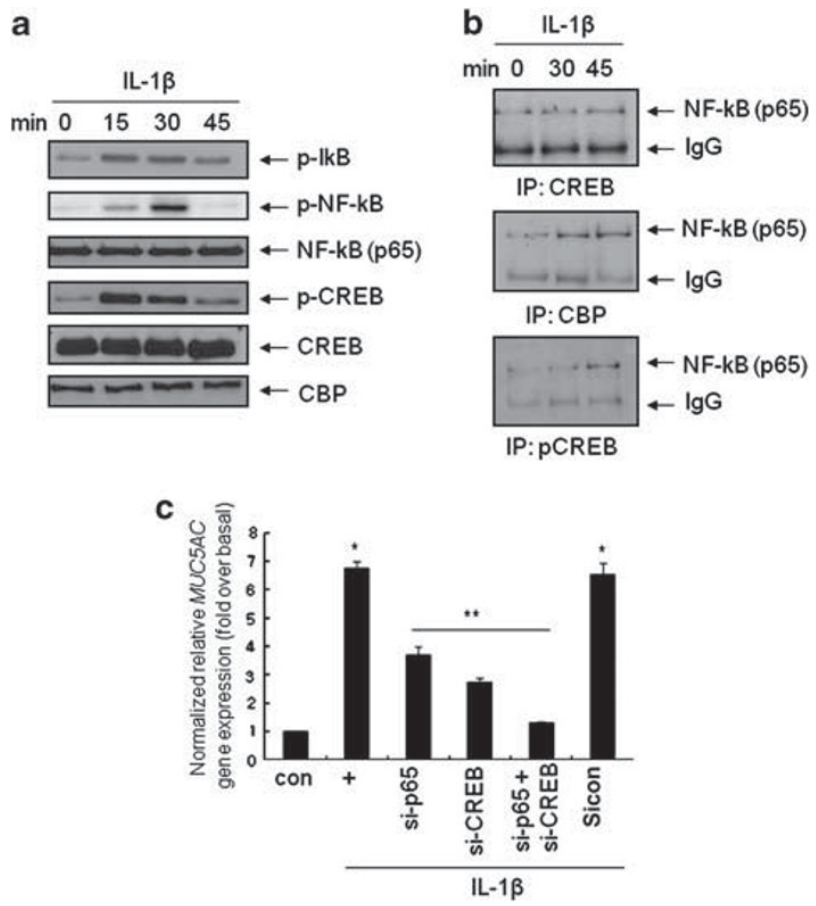

Figure 1 Interleukin (IL)-1 $\beta$ induces the interaction of NF- $\mathrm{kB}$ with CAMP response element-binding protein (CREB) to enhance MUC5AC gene expression in $\mathrm{NCl}-\mathrm{H} 292$ cells. (a) Confluent and quiescent $\mathrm{NCl}-$ $\mathrm{H} 292$ cells were treated with IL- $1 \beta\left(10 \mathrm{ng} \mathrm{ml}^{-1}\right)$ for the indicated times, then lysates were harvested and analyzed by Western blot using several antibodies. Total NF- $\mathrm{KB}$ and CREB-binding protein (CBP) were used as loading controls. (b) Cells were treated for the indicated times (min) and total lysates were then immunoprecipitated with anti-CREB, CBP, or phospho-CREB antibody, and blotted with anti-p65 antibody. IgG bands were used as a loading control. IP, immunoprecipitation. (c) After cells were transfected with the small interfering RNA constructs of p65, CREB, or both, cells were treated with IL-1 $\beta$ for $24 \mathrm{~h}$ before the collection of total RNA for real-time quantitative real-time PCR. ${ }^{*} P<0.05$ compared with the control and ${ }^{* *} P<0.05$ compared with IL-1 $\beta$ treatment only. The figures are representative of three independent experiments.

Both the CREB and NF- $\kappa B$ siRNA may have an additive function in the suppression of MUC5AC gene expression. These findings indicate that the interaction of NF- $\mathrm{KB}$ with CREB may be necessary for IL-1 $\beta$-induced MUC5AC transcription in human airway epithelial cells.

\section{c-Ets1 transcription factor functions as a suppressor in IL-1 $\beta$ - induced MUC5AC transcription}

To identify the IL- $1 \beta$-responsive region within the MUC5AC promoter, NCI-H292 cells were transiently transfected with various deletion mutants and were treated with IL-1 $\beta$ for $24 \mathrm{~h}$. IL- $1 \beta$ selectively increased the luciferase activity of the $-929 /-1$ region of the MUC5AC promoter, whereas the IL-1 $\beta$-induced luciferase activity of the $-950 /-1$ region of the $M U C 5 A C$ promoter was not affected. This finding indicates that the $-950 /-929$ region of the MUC5AC promoter may be necessary for its response to IL-1 $\beta$ as a suppressor (Figure 2a). Interestingly, there is no CRE site in the -950/-929 region. This finding suggests that a transcription factor other than CREB may have a crucial role in MUC5AC transcription. 


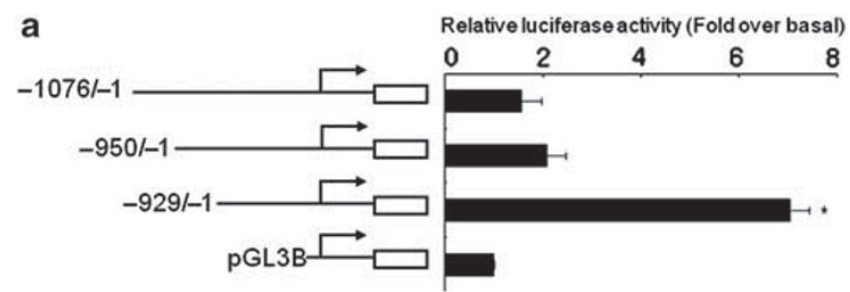

b
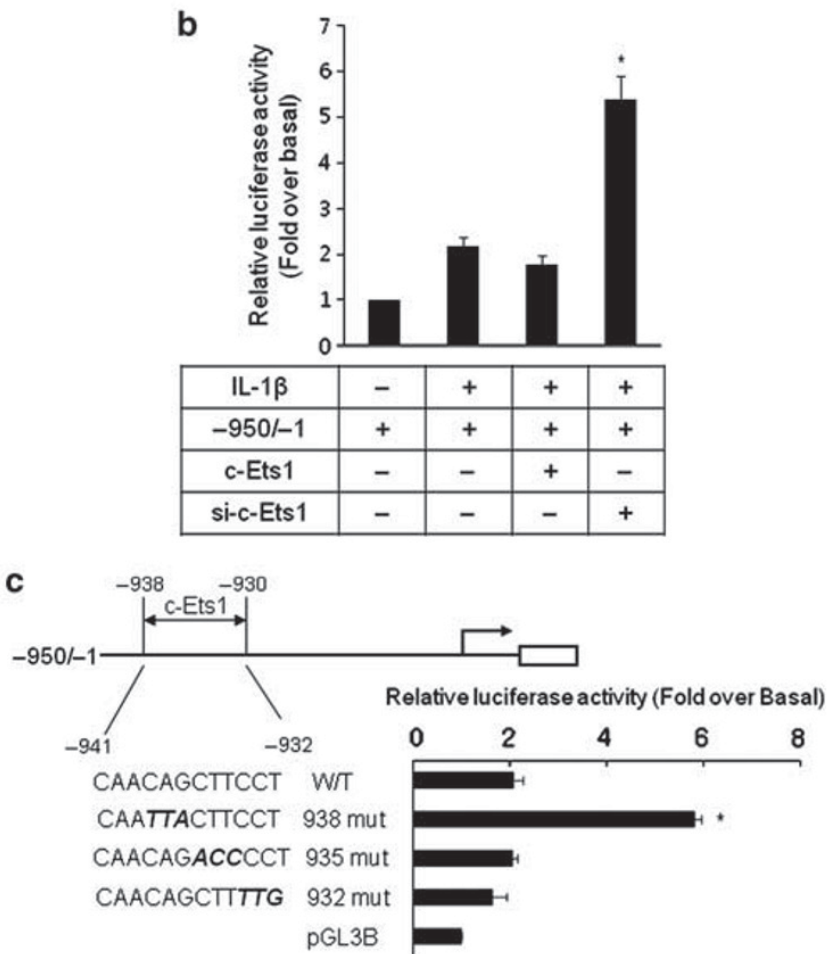

Figure 2 Interleukin (IL)-1 $\beta$-induced MUC5AC transcription was downregulated by the cis-acting c-Ets1 regulatory motif in $\mathrm{NCl}-\mathrm{H} 292$ cells. (a) The cells were transfected with several luciferase reporter constructs encoding the MUC5AC promoter and treated with IL-1 $\beta$ $\left(10 \mathrm{ng} \mathrm{ml}^{-1}\right)$ for $24 \mathrm{~h}$. Cell lysates were analyzed with a reporter assay according to the manufacturer's instructions. ${ }^{\star} P<0.05$ compared with the $-950 /-1$ reporter construct. (b) The cells were cotransfected with pGL3B::MUC5AC -950/-1 and either the wild-type c-Ets1 expression construct or the small interfering RNA-c-Ets1 construct, and then treated with IL-1 $\beta\left(10 \mathrm{ng} \mathrm{ml}^{-1}\right)$ for $24 \mathrm{~h} .{ }^{*} P<0.05$ compared with the $-950 /-1$ reporter construct. (c) Site-directed mutagenesis was carried out to generate the construct c-Ets1-binding site mutants as indicated. After treatment with IL-1 $\beta$ for $24 \mathrm{~h}$, cell lysates were harvested. Displayed luciferase activities are shown after correction for transfection efficiency using the $\beta$-galactosidase activity of the cell lysates. Values shown are mean \pm s.d. of experiments performed in triplicate. ${ }^{\star} P<0.05$ compared with the wild-type reporter construct.

We used the TFSEARCH Ver. 1.3 database (http://www.cbrc. $\mathrm{jp} /$ research/db/TFSEARCH.html) to identify the IL-1 $\beta$-responsive cis-element in the MUC5AC promoter, and this search strategy identified a candidate, $\mathrm{c}$-Ets1 (score $=91.2$; threshold: 90.0). ${ }^{9}$ To further investigate whether c-Ets1, which was found within the -938/-930 region of the MUC5AC promoter, might act as a cis element, cotransfection with the $-950 /-1$ reporter construct and either wild-type c-Ets1 expression construct or siRNA-c-Ets1 construct was performed to determine its effect on MUC5AC transcription activity. Wild-type c-Ets1 did not affect the luciferase activity of $-950 /-1$ region of the MUC5AC promoter, whereas the siRNA-c-Ets1 increased the activity (Figure 2b). Moreover, we examined whether c-Ets1 acts as a suppressor. Three mutant constructs were generated to represent the selective mutagenesis of the c-Ets1-binding site. Only the -938 mutant construct increased the responsiveness of the wild-type $M U C 5 A C$ promoter construct (Figure 2c). However, the -935 and -932 mutant constructs were able to suppress luciferase activity. These results suggest that the c-Ets1 ( $-938 /-930$ region) in the regulatory region of the MUC5AC promoter may be critical for IL- $1 \beta$-induced suppression of MUC5AC transcriptional activity.

\section{c-Ets1 can dissociate the interaction of NF- $k B$ with CREB to suppress IL-1 $\beta$-induced MUC5AC gene expression}

To further investigate the effect of the IL- $1 \beta$ on c-Ets 1 activity, cells were treated with IL- $1 \beta$ in a time-dependent manner, and c-Ets1 phosphorylation was analyzed by Western blot using a specific antibody against phosphorylated c-Ets1 (pSer282). c-Ets 1 was phosphorylated $30 \mathrm{~min}$ after IL- $1 \beta$ treatment, and this persisted for up to $60 \mathrm{~min}$ (Figure 3a). To examine whether c-Ets1 affects IL-1 $\beta$-induced MUC5AC gene expression, transient transfection with a plasmid construct encoding either wild-type c-Ets1 or siRNA-c-Ets1 was performed (Figure $\mathbf{3 b}$ ). The wild-type c-Ets1 suppressed IL- $1 \beta$-induced MUC5AC gene expression, whereas siRNA-c-Ets1 upregulated MUC5AC gene expression, demonstrating that c-Ets1 may have a suppressive role in IL-1 $\beta$-induced MUC5AC gene expression in NCI-H292 cells. We performed electrophoretic mobility shift assay experiments using nuclear extracts from NCI-H292 cells after IL-1 $\beta$ treatment to further determine whether c-Ets1 directly affects the IL-1 $\beta$-induced interaction of CREB with the CRE of the MUC5AC promoter. ${ }^{5}$ For electrophoretic mobility shift assay, oligonucleotides corresponding to CRE-specific sequences in the MUC5AC promoter region -878 to -871 ( $5^{\prime}$-AGAGATTGC CTGACTTGAAGAGCTAG- ${ }^{\prime}$ ) were synthesized. The activity of MUC5AC-specific CRE increased remarkably in response to IL-1 $\beta$ (Figure 3c). However, overexpressed c-Ets1 dissociated the interaction of CREB with the CRE site of the MUC5AC promoter, whereas siRNA-c-Ets1 did not have such an effect. To distinguish any specific CRE-binding complexes, competition analysis was performed using 50-fold excesses of non-radiolabeled (cold) CRE oligonucleotide. The specific band was selectively inhibited by the cold-CRE oligonucleotide, indicating that overexpressed c-Ets1 functions as a suppressor by disrupting the interaction of activated CREB with either a cis-acting element, $\mathrm{CRE}$, or another transcription factor(s) in the MUC5AC promoter. Furthermore, to examine whether overexpressed c-Ets1 affects the interaction of NF- $\kappa B$ with CREB to regulate IL- $1 \beta$ induced MUC5AC gene expression, we performed an immunoprecipitation assay with anti-p65 IgG in c-Ets1-overexppressed cells (Figure 3d). Overexpressed c-Ets1 inhibited the interaction of CREB with NF- $\kappa B$ after IL- $1 \beta$ treatment, whereas siRNAc-Ets1 did not affect the protein complex, indicating that c-Ets1 dissociated the CREB-NF- $\kappa B$ complex to attenuate the IL- $1 \beta$ induced physiological phenomena. These results are noteworthy 


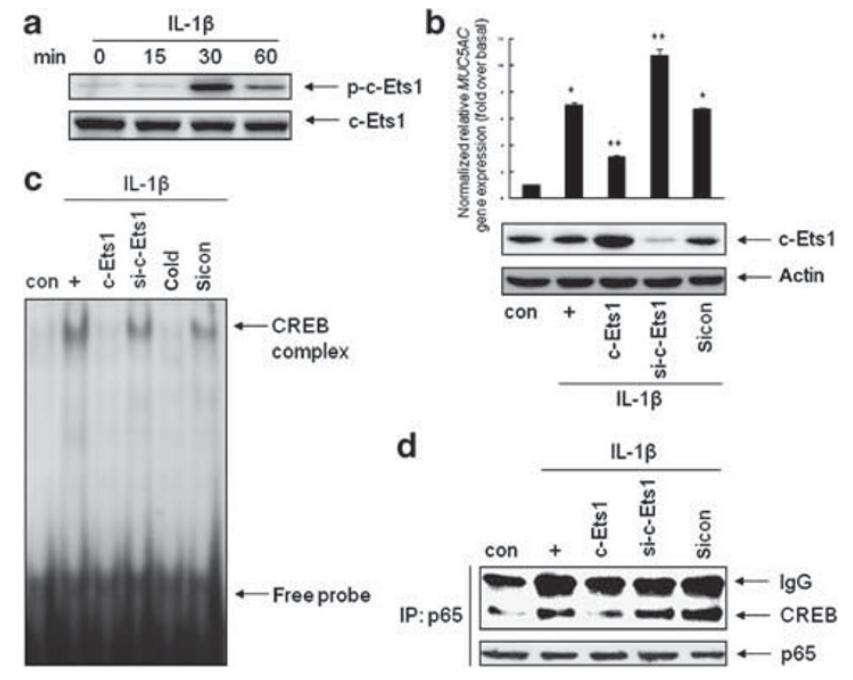

Figure $3 \mathrm{c}$-Ets1 can downregulate MUC5AC gene expression by disrupting the interaction of NF- $\mathrm{kB}$ with cAMP response element-binding protein (CREB). (a) Confluent cells were treated with interleukin (IL)-1 $\beta$ $\left(10 \mathrm{ng} \mathrm{ml}^{-1}\right)$ for the indicated times, then cell lysates were analyzed by Western blot with phospho-c-Ets1 antibody. Total c-Ets1 expression was used as a loading control. (b) Cells were transiently transfected with either wild-type or the small interfering RNA (siRNA) construct of $c$-Ets 1 or a siRNA control. Cells were serum-starved and treated with $\mathrm{IL}-1 \beta\left(10 \mathrm{ng} \mathrm{ml}^{-1}\right)$ for $24 \mathrm{~h}$, after which cell lysates were harvested for Western blot analysis and real-time PCR. ${ }^{*} P<0.05$ compared with the control; ${ }^{* \star} P<0.05$ compared with IL-1 $\beta$ treatment. (c) Cells were transiently transfected with either the wild-type or the siRNA construct of c-Ets 1 or a siRNA control. Cells were serum-starved and treated with IL-1 $\beta\left(10 \mathrm{ng} \mathrm{ml}^{-1}\right)$ for $30 \mathrm{~min}$. Nuclear protein extracts from IL-1 $\beta$ treated $\mathrm{NCl}-\mathrm{H} 292$ cells were subjected to electrophoretic mobility shift assay (EMSA). Nuclear proteins were incubated with $\left[\gamma^{-32} \mathrm{P}\right]$-labeled CRE oligonucleotides or a 50 -fold excess of cold CRE probe before EMSA. The labeled nuclear proteins were separated by electrophoresis on $5 \%$ polyacrylamide gels, and the gels were dried and exposed to autoradiography at $-70^{\circ} \mathrm{C}$ overnight. (d) Confluent and quiescent cells were transfected with either the wild-type or the siRNA construct of c-Ets1 or a siRNA control, then treated for 30 min with IL-1 $\beta$. Total cell lysates were then immunoprecipitated with anti-c-Ets1 antibody and blotted with CREB antibody. IP: immunoprecipitation; IB: immunoblotting. Displayed figures are representative of three independent experiments.

because several reports have shown that c-Ets1 can bind to $\mathrm{CBP} / \mathrm{p} 300$ but not to CREB. ${ }^{17-19}$ Thus, our results suggest that c-Ets1 may have a suppressive role in IL-1 $\beta$-induced MUC5AC gene expression by negatively regulating the interaction of NF$\kappa \mathrm{B}$ with CREB.

\section{c-Ets1 inhibits IL-1 $\beta$-induced mucous metaplasia, cell populations, and inflammatory proteins in mouse lungs}

First, we examined whether the sh-c-Ets1 virus suppressed endogenous c-Ets1 protein levels. After viral infection into the right nostril of the mice, we verified that these viruses had wellexpressed coding proteins (Figure 4a). In order to investigate whether IL-1 $\beta$-induced $M U C 5 A C$ gene expression might be regulated by c-Ets 1 in vivo as well as in vitro, tracheotomies were performed to instill IL-1 $\beta$ into either control or virus-infected mice. IL-1 $\beta$-induced $M U C 5 A C$ gene expression was dramatically decreased in the mice infected with the virus expressing wildtype c-Ets1 compared with those infected with the virus express- ing sh-c-Ets1 (Figure 4b). Periodic acid-schiff (PAS) staining, which was achieved by inducing mucous metaplasia with IL-1 $\beta$ treatment in viruses-infected mice, was used to determine whether c-Ets 1 acts as a negative regulator of the mucin granule exocytic complex during IL- $1 \beta$-induced inflammation. The lungs from the infected mice were sectioned and stained with PAS. The airways of the IL-1 $\beta$-instilled mice were found to be highly metaplastic, as they stained strongly with PAS (Figure 4cii). However, wild-type c-Ets1 overexpression inhibited IL-1 $\beta$ induced mucous metaplasia (Figure 4ciii) whereas sh-RNA-cEts1 had no effect (Figure 4civ). Inflammation is characterized by infiltration of eosinophilic leukocytes and T-helper type 2 lymphocytes. ${ }^{20}$ Eosinophils were the main constituent inflammatory cells in mice infected with viruses expressing either wildtype or shRNA-c-Ets1 that were treated with IL-1 $\beta$. However, IL-1 $\beta$-induced eosinophil production was not significantly higher in mice infected with virus expressing either wild-type or sh-RNA-c-Ets1 compared with wild-type mice (data not shown). Mice infected with virus-expressing sh-RNA-c-Ets1 had more lymphocytes, neutrophils, alveolar macrophages (AMs), and total protein levels in bronchoalveolar lavage (BAL) fluid, whereas those infected with virus expressing wild-type c-Ets1 had significantly decreased levels of such markers, compared with the IL-1 $\beta$-instilled mice (Figure 4d). However, after IL-1 $\beta$ treatment, the total cell numbers peaked on day 7 in wild-type mice and declined until day 10 . Moreover, to investigate the effect of c-Ets1 overexpression on modulation of inflammatory proteins after instillation of IL- $1 \beta$, specific enzyme-linked immunosorbent assay (ELISA) kits were used (Figure 4e). The levels of inflammatory cytokines and the anti-inflammatory mediator, transforming growth factor (TGF)- $\beta 1$, in the first BAL fluid were analyzed 3 days after IL- $1 \beta$ treatment. c-Ets1 overexpression suppressed IL-1 $\beta$-induced MIP2 and tumor necrosis factor (TNF)- $\alpha$ production, whereas shRNA-c-Ets1 expression increased the production of these proteins. Interestingly, TGF- $\beta 1$ was increased in BAL fluid collected from the c-Ets-infected mice. These results show that $c$-Ets 1 could reduce mucous metaplasia and inflammatory cell recruitment in BAL fluid after IL- $1 \beta$ treatment, suggesting that $\mathrm{c}$-Ets1 functions as an important suppressor in IL-1 $\beta$-induced inflammation in vivo.

\section{ROS produced by NOX4 is essential for IL-1 $\beta$-induced $c$-Ets 1 gene expression in AMs}

The c-Ets1 transcription factor induced cytokine and chemokine gene expression to regulate inflammation in Ets-1 knockout mice. ${ }^{21}$ However, little is known about a role for ETS factors in regulating inflammation in AMs. Accordingly, we investigated whether c-Ets1 could regulate inflammatory cytokine gene expression in AMs. Mice were infected with viruses and killed 3 days post IL- $1 \beta$ instillation. The AM cells obtained via BAL of the lungs harvested from the killed mice were subsequently incubated. c-Ets1 overexpression inhibited expressions of the MIP2 and TNF- $\alpha$ gene in AM cells, whereas shRNA-c-Ets1 increased the expression of these genes (Figure 5a). These results are consistent with those found for BAL fluid (Figure 4e). To examine whether IL- $1 \beta$ can produce ROS, flow cytometry 
a

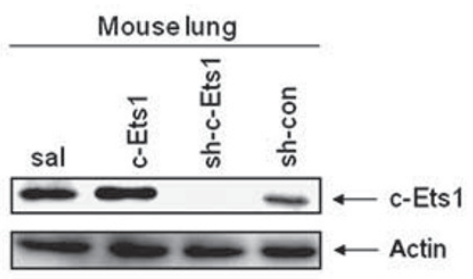

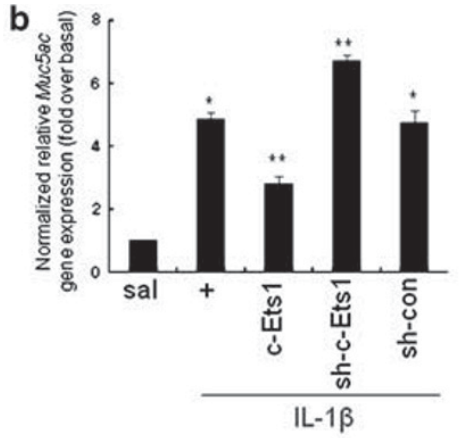

c
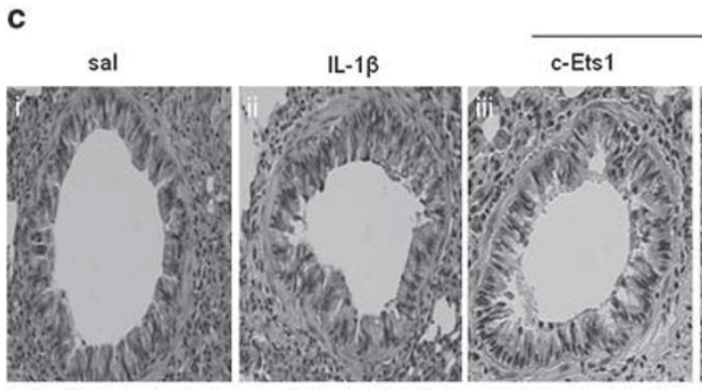

IL-1 $\beta$
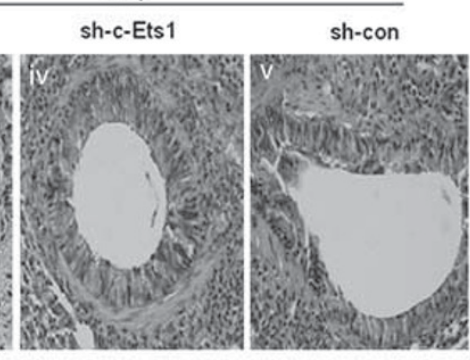

d
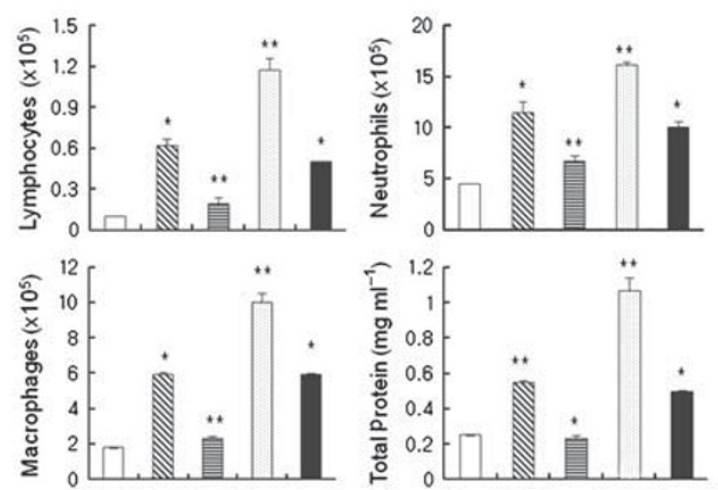
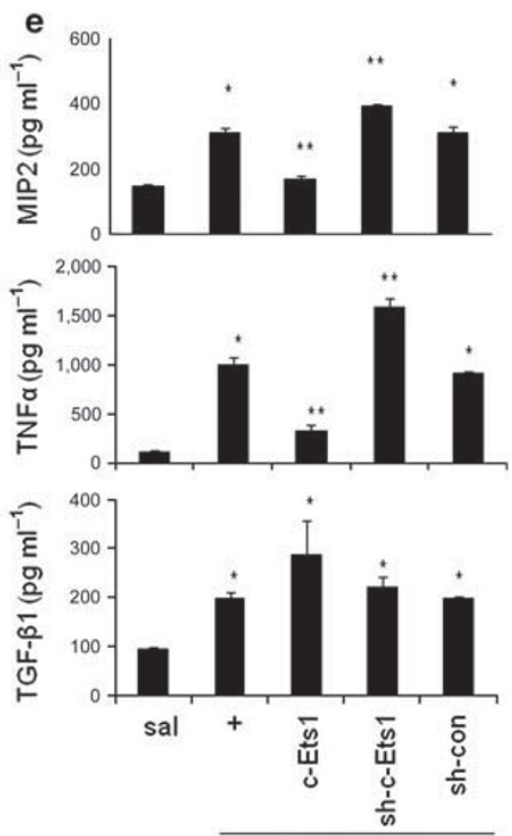

IL-1ß

Figure 4 c-Ets1 suppressed interleukin (IL)-1 $\beta$-induced lung inflammatory responses in vivo. (a) Lenti::c-Ets1, shlenti::c-Ets1, or lenti::luciferase (multiplicity of infection 30) was administered drop by drop to the right nostril. After 3 days, lungs from the killed mice were obtained and analyzed by Western blot with c-Ets1 antibody to determine the endogenous c-Ets1 expression level $(n=4)$. (b) Three days after infection, $50 \mu$ l of $200 \mathrm{ng}$ of IL-1 $\beta$ or saline was instilled inside the trachea, and $24 \mathrm{~h}$ later, the lungs were processed for $\mathrm{PCR} .{ }^{*} P<0.05$ compared with saline-treated mice and ${ }^{* \star} P<0.05$ compared with IL-1 $\beta$-treated mice $(n=4)$. Figures shown are representative of three independent experiments. (c) One week after IL-1 $\beta$ instillation $(50 \mu \mathrm{l}$ of $200 \mathrm{ng})$ into the lumen of the trachea of mice infected with the virus encoding wild-type c-Ets 1 or shRNA-c-Ets 1 , periodic acid-Schiff staining was performed in the lung $(n=4)$. (d) Mice were infected with viruses and killed 3 days post IL-1 $\beta$ instillation $(50 \mu l$ of $200 \mathrm{ng})$, and lymphocytes, neutrophils, alveolar macrophages, and total protein levels in bronchoalveolar lavage (BAL) fluid were measured. ${ }^{\star} P<0.05$ compared with salinetreated mice and ${ }^{* *} P<0.05$ compared with IL-1 $\beta$-treated mice $(n=4)$. (e) The levels of MIP-2, tumor necrosis factor (TNF)- $\alpha$, and transforming growth factor (TGF)- $\beta 1$ proteins in BAL fluid were measured using specific enzyme-linked immunosorbent assay kits. ${ }^{*} P<0.05$ compared with saline-treated mice and ${ }^{* *} P<0.05$ compared with IL-1 $\beta$-treated mice $(n=4)$.

was used. ROS production was increased at $5 \mathrm{~min}$ and decreased at $10 \mathrm{~min}$ (Figure $\mathbf{5 b}$ ). In addition, ROS production was unaffected AM cell viability (Figure 5c). To determine whether IL-1 $\beta$ induces a significant increase in the expression of NOX subtypes and to identify which NOX subtypes are involved in intracellular ROS production within AM cells, cells were treated with IL-1 $\beta$ in a time-dependent manner and real-time PCR was performed. Interestingly, only NOX4 gene expression increased significantly 20 min after IL- $1 \beta$ treatment (Figure 5d). We used siRNANOX4 to verify the function of NOX4. Expression of the $c$-Ets1 and $M u c 5 a c$ gene was inhibited by siRNA-NOX4 (Figure 5e). These results suggest that NOX4 is not only a critical NOX homolog in AM cells in response to IL- $1 \beta$, but also is essential for IL-1 $\beta$-induced intracellular ROS generation and expressions of both $c$-Ets1 and Muc5ac gene.

\section{DISCUSSION}

This study was a detailed investigation of the negative regulation of the inflammation signaling mechanism, with special emphasis on the transcription factor c-Ets1. The in vitro and in vivo studies showed that c-Ets1 regulates MUC5AC overproduction through at least two different pathways. These pathways include functioning as an activator binding to CREB after adenosine triphosphate (ATP) treatment, and functioning as an attenuator. ${ }^{9}$ 

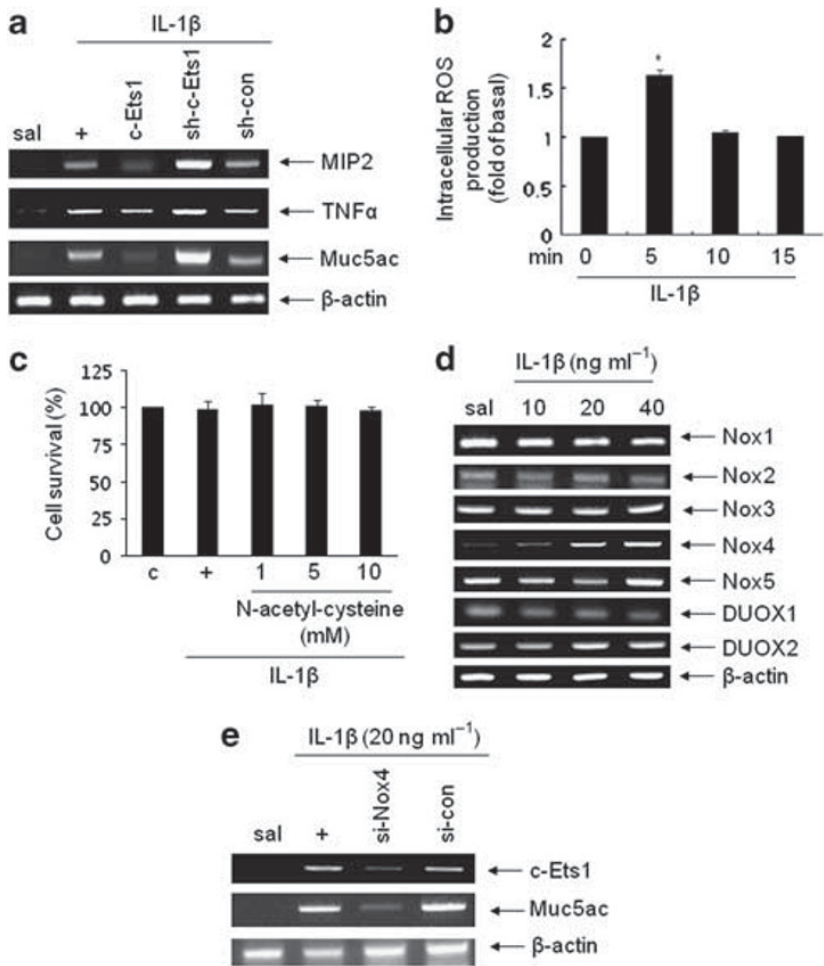

Figure 5 Effect of reactive oxygen species (ROS) produced by NOX4 on c-Ets1 and MUC5AC gene expression in alveolar macrophage cells. (a) Mice were infected with viruses and killed 3 days post interleukin (IL) $-1 \beta$ instillation ( $50 \mu \mathrm{l}$ of $200 \mathrm{ng}$ ), and alveolar macrophage (AM) cells from bronchoalveolar lavage fluid $(n=4)$ were incubated. After $24 \mathrm{~h}$, real-time (RT)-PCR was performed with specific primers. (b) The AM cells from saline-treated mice were pre-incubated in the presence of $50 \mu \mathrm{M} 2^{\prime}, 7^{\prime}$-dichlorofluorescein diacetate for $30 \mathrm{~min}$, and then exposed to IL-1 $\beta\left(20 \mathrm{ng} \mathrm{ml}^{-1}\right)$ for the indicated periods. Cell-associated $2^{\prime}, 7^{\prime}$ dichlorofluorescein levels were analyzed by flow cytometry. ${ }^{\star} P<0.05$ compared with saline-treated mice $(n=4)$. (c) The AM cells from salinetreated mice were pre-incubated in the presence of $\mathrm{N}$-acetyl-cysteine for $1 \mathrm{~h}$ in a dose-dependent manner, and then treated with IL-1 $\beta\left(20 \mathrm{ng} \mathrm{ml}^{-1}\right)$ for $1 \mathrm{~h}$. A cell proliferation assay was performed with CCK-8 (Dojindo, Rockville, MD) $(n=4)$. (d) The AM cells from saline-treated mice $(n=4)$ were exposed to IL-1 $\beta\left(20 \mathrm{ng} \mathrm{ml}^{-1}\right)$ for the indicated times, and then were performed RT-PCR with specific primers. ${ }^{38}$ (e) The AM cells from saline-treated mice $(n=4)$ were transiently transfected with either the small interfering RNA (siRNA) construct of NOX4 or a siRNA control. Cells were treated with IL-1 $\beta\left(20 \mathrm{ng} \mathrm{ml}^{-1}\right)$ for $24 \mathrm{~h}$, and RT-PCR was subsequently performed. Representative results for more than three independent experiments are shown for each group.

The transcription factor interactions affect the positive/ negative regulation of the stimulant-induced expression of some genes. In our previous study, we found that the interaction of CREB with c-Ets1 resulted in ATP-induced MUC5AC gene expression, ${ }^{9}$ suggesting that one or more transcription factor(s) are recruited by transcription factor complexes, because inflammatory conditions should increase stimulant-induced mucin gene expression. In fact, IL- $1 \beta$ can activate a number of transcriptional factors to induce many physiological phenomena. However, there are few studies of the negative regulation mechanism/signaling of mucous hypersecretion with respect to IL-1 $\beta$-induced mucin gene expression. Understanding the biochemical properties of protein-protein interactions in the alteration of signal transduction should provide further understanding of biological phenomena as well as additional insight into the signal transduction leading to the regulation of intracellular signaling. It has been reported that either the NF- $\kappa \mathrm{B}$ or CREB signaling pathways are essential for IL-1 $\beta$-induced MUC5AC overexpression in the airway. ${ }^{5,22}$ In this study, both pathways were found to function largely in MUC5AC overexpression by interacting with each other and sharing the signaling required for complementation and augmentation to be properly performed in the respiratory tract. Nevertheless, the reason for this interaction remains unclear and the mechanism underlying negative regulation has yet to be clarified. Determining the way in which MUC5AC overexpression is either downregulated or suppressed to maintain homeostasis may support the development of new therapeutic medication to control mucus overproduction. We, therefore, investigated a candidate protein for the downregulation of the interaction of NF- $\mathrm{KB}$ with CREB in the airway.

Until now, there have been a number of reports on IL-1 $\beta$ induced MUC5AC gene expression in the human airway. However, most of the studies on IL- $1 \beta$ have assumed it to be an upregulation mediator of inflammation when investigating intracellular signaling pathways. ${ }^{23,24}$ As many studies on the function of c-Ets1 in inflammation have focused on modulated physiological phenomena, ${ }^{25,26}$ the negative effect of c-Ets1 on cytokine-induced mucus hyperproduction and mucous hypersecretion during inflammation remains unclear. With the exception of our previous study, ${ }^{9}$ there have been no reports on c-Ets1-regulated mucin overproduction in the airway. We speculated that IL- $1 \beta$-induced c-Ets1 activation can function as an intracellular suppressor by inhibiting several transcription factors in the airway as well as inhibiting cancer cell proliferation by binding to $553{ }^{27,28}$

The most significant finding of this study is that c-Ets1 negatively regulated IL- $1 \beta$-induced MUC5AC overexpression both in vitro and in vivo by dramatically disrupting the interaction of NF- $\kappa B$ with CREB (Figure 3d). Previously, we reported that c-Ets1 functions as a co-activator of ATP-induced MUC5AC overexpression by binding to the ATP-activated CREB transcription factor in the airway. ${ }^{9}$ Thus, we wondered if c-Ets1 has a dual function or if it recruits negative factors to abolish intracellular signaling. Our results show that c-Ets1 regulates the dynamics of the interaction between NF- $\kappa B$ and CREB facilitated by IL- $1 \beta$, which is supported by the finding that the c-Ets site $(-930)$ is located very close to the NF- $\mathrm{KB}$ site $(-956)^{29}$ and the CREB site $(-878)^{5}$ in the MUC5AC promoter. Accordingly, we hypothesized that c-Ets1 functions as an important suppressor of IL$1 \beta$-induced MUC5AC overproduction, at least in part, in the airway epithelium. However, we found that binding of CREB to c-Ets1 for ATP signaling enhanced MUC5AC gene expression in NCI-H292 cells. ${ }^{9}$ This discrepancy may be due to (1) secondary effects of signaling for c-Ets1 activation at the receptor level; (2) c-Ets1 functioning as a signaling conductor; or (3) differences in the type of stimuli because signal transduction may rely heavily on the interaction of stimulants with their own receptors or molecules. These conjectures indicate that even c-Ets1 with transient signaling capability may act as a signaling molecule by 
amplifying the signal, thus producing the correlated physiological phenomena. Additionally, we suppose that activated c-Ets1 may regulate the dynamics of the interaction between CREB and NF- $\kappa \mathrm{B}$, thereby negatively regulating mucous overproduction. Our hypothesis is supported by the finding that c-Ets 1 can bind to other transcription factors, such as AP- $1, \mathrm{NF}-\kappa \mathrm{B}$, and the Pax family, in response to diverse signals. ${ }^{10}$ However, the main difference between our findings and those previously reported in the literature is that we observed that c-Ets1 dissociated the interacted NF- $\kappa B$ and CREB, thereby dissociating the protein complex to regulate mucus overproduction during airway inflammation.

More interestingly, c-Ets1 functioned as a negative regulator in vivo in the mouse lung model (Figure $\mathbf{4 b}$ ). We used mouse lungs, but not tracheas, to detect morphological differences largely in Muc5ac overproduction. We had difficulty detecting such differences using mouse tracheas after lipopolysaccharide instillation because the differences between the sham mice and the challenged mice were undetectable. ${ }^{1}$ One possible reason for this finding was that the activator solution may have passed through the trachea without affecting mucus expression in the mouse tracheas. Thus, in the present study, lungs were selected in order to detect more dramatic morphological changes. Interestingly, IL-1 $\beta$-induced mucous metaplasia, neutrophils, and AMs were decreased by c-Ets1, whereas shRNA-c-Ets 1 increased mucous metaplasia, suggesting that c-Ets1 functions as a negative regulator to maintain homeostasis by disrupting the interaction of NF- $\mathrm{\kappa B}$ with CREB in vivo. However, it is still unclear whether $\mathrm{c}$-Ets1 has consequences for IL-1 $\beta$-induced mucous metaplasia and Muc5ac overproduction. Based on the results of our previous study ${ }^{9}$ and the present study, c-Ets1 may influence physiological phenomena according to its role as a suppressor or activator in intracellular signaling. Even though such a result provides insight into the regulatory mechanism of mucus hyperproduction, an understanding of how c-Ets1 can regulate the amount of total protein, AMs, and neutrophils in BAL fluid is still unclear. In addition, if c-Ets1 functions in BAL fluid as well as in vivo, it may be related to apoptotic cell clearance in acute lung injuries. ${ }^{30}$

NOX4 is expressed predominantly in goblet cells in normal human nasal epithelial cells and might function in the induction of the expressions of both MUC5AC and MUC8 gene. ${ }^{31,32}$ In addition, Lee et al. ${ }^{33}$ reported that NOX4 was expressed in human monocytes and mature macrophages. ROS activates the JAK-STAT pathway, which in turn contributes to goblet cell metaplasia, a major player in mucin production and airway clogging. ${ }^{34}$ Recently, Severgnini et al. ${ }^{35}$ showed that ROS regulates STAT activation in acute lung injuries. The importance of NOX4 for mucus hyperproduction and mucous hypersecretion is becoming increasingly apparent. In this study, we showed that siRNA-NOX4 decreased $c$-Ets 1 and Muc5ac gene expression in AM cells (Figure 5e), suggesting that NOX may have critical functions in airway inflammation and may regulate ROS production to maintain homeostasis in the airway.

Although MUC5AC was mainly expressed in epithelial cells and goblet cells, we found that lipopolysaccharide could induce
Muc5ac gene expression in the mouse leukemic monocyte macrophage cell line, Raw 264.7 (KSS, unpublished data). Thus, we postulated that Muc5ac is expressed in AM cells to induce inflammation or to affect the microenvironment. Fortunately, Muc5ac was expressed in cultured AM cells, suggesting that Muc5ac may cause an inflamed condition or recruit several inflammatory proteins or cells. Accordingly, expressed Muc5ac in AM cells may induce/regulate the inflammatory microenvironment. In addition, IL-1 $\beta$ induced $c$-Ets 1 and Muc5ac gene expression in AM cells through activation of NOX4. Although c-Ets1 inhibited MUC5AC overproduction (Figures $\mathbf{3 b}$ and $\mathbf{4 b}$ ), there are three potential reasons for the induced expression of these genes, which have either an inflammatory function or a suppressive function. First, when inflammation is severe in the airway, suppressor proteins are overexpressed and inhibit mucus hyperproduction through c-Ets1's inhibitory function. Second, IL- $1 \beta$ induces more active MUC5AC gene expression than c-Ets1 in order to increase mucus hyperproduction in inflammatory conditions. Third, IL-1 $\beta$ can induce production of the same levels of these proteins; however, some protein(s) abolish c-Ets1 gene expression. We assert that cells can regulate the balance between the production of these proteins to maintain homeostasis.

In conclusion, we found that the interaction of NF- $\kappa \mathrm{B}$ with CREB enhanced IL- $1 \beta$-induced MUC5AC overproduction and the effect of the interaction was mutually additive. In addition, our findings showed that c-Ets1 could negatively regulate MUC5AC overproduction by inhibiting the protein-protein interaction both in vitro and in vivo, indicating that c-Ets 1 induces the reduction of mucous metaplasia, the number of AMs and neutrophils, and decreases MUC5AC overproduction. Moreover, ROS produced by NOX4 may transfer the signal to alter the inflammatory process in vivo. Thus, these results suggest that c-Ets1 may be a potential therapeutic candidate to treat mucus hyperproduction by inhibiting the protein-protein interactions involved in MUC5AC overproduction.

\section{METHODS}

Materials. IL-1 $\beta$ was purchased from R\&D Systems (Minneapolis, MN). All antibodies were purchased from Cell Signaling (Beverly, MA), except the c-Ets1 antibody, which was purchased from Abcam (Cambridge, MA). The following siRNAs were synthesized by Bioneer (Daejeon, Korea): p65, 5' -GCCCUAUCCCUUUACGUCA(dTdT)-3'; CREB, 5' UCAAGGAGGCCUUCCUACA(dTdT)-3'; c-Ets1, 5' -GCUGACCUC AAUAAGGACA(dTdT)-3'; murine NOX4, 5' -AACGAAGGGGUUA AACACCUC(dTdT)-3', and negative control, 5' -CCUACGCCACCA AUUUCGU(dTdT)-3'.

Cell transfection. For transfection, cells were plated in 6-well plates one day before transfection with plasmid DNA ( $1 \mu \mathrm{g}$ per well) or siRNA (100 pmole per well) using FuGENE HD (Roche; Indianapolis, IN) according to the manufacturer's instructions. Approximately $24 \mathrm{~h}$ after transfection, cells were maintained in $0.2 \%$ serum RPMI media for $16-18 \mathrm{~h}$ before treatment with IL-1 $\beta$, and then harvested.

Tracheotomy. The 6- to 8-week-old C57BL/6 mice were maintained in accordance with the guidelines and under the approval of the Animal Care Committee of Kosin University College of Medicine, Busan, Korea. For intratracheal instillation, mice were anesthetized and their tracheas were surgically exposed by making an incision 
in the neck skin. IL-1 $\beta$ solution $(200 \mathrm{ng}$ per $50 \mu \mathrm{l})$ or saline $(50 \mu \mathrm{l})$ was injected into the exposed trachea using a microsyringe equipped with a 31-gauge needle. The skin was subsequently sutured, and the mice were killed, and their lungs were removed $24 \mathrm{~h}$ after infection. ${ }^{36}$

Virus production and in vivo intranasal instillation for infection. Vector constructions of LentiM1.2::c-Ets1, shLentiM3.4:: c-Ets1, and shLentiM3.4::luciferase, and virus production were performed by Macrogen (Seoul, Korea). The sequences targeted were: sh-c-Ets1, 5' -AGGTGTGGACTTCCAGAAG-3' and luciferase, 5' $^{\prime}$-CTTACGCTG AGTACTTCGA-3'. Viral suspensions (multiplicity of infection 30) were administered drop by drop to the right nostril of the mice underanesthesia using gel-loading pipette tips. ${ }^{37}$ Tracheotomies were performed 3 days after infection.

PAS staining. The mice lungs were fixed in $10 \%$ buffered neutral formalin, embedded in paraffin, and sectioned. For PAS staining, serial sections were collected on coated slides. The slides were treated with $3 \%$ glacial acetic acid for $3 \mathrm{~min}$, and then incubated with $0.5 \%$ periodic acid solution for $5 \mathrm{~min}$, and then rinsed with phosphate-buffered saline buffer. The sections were then reacted with Schiff solution, washed in tap water, and counterstained with Harris hematoxylin.

BAL cells, primary cell culture, and ELISA. BAL was performed by slowly injecting $1 \mathrm{ml}$ of ice-cold phosphate-buffered saline, through the tracheal tube. The fluid was slowly obtained by gentle suction immediately after delivery, and cell counts were determined using an electronic Coulter Counter fitted with a cell sizing analyzer (Coulter Model ZBI with a channelizer 256; Coulter Electronics, Bedfordshire, $\mathrm{UK}){ }^{30}$ Alveolar macrophages were isolated by adhesion $(2 \mathrm{~h})$ and cultured in serum-free X-Vivo 10 medium (BioWhittaker, Walkersville, MA). MIP-2, TNF- $\alpha$, and TGF- $\beta$ protein levels were measured from the first BAL fluid with specific ELISA kits (R\&D systems).

Analysis of cellular ROS levels. Cellular ROS levels were analyzed using the $2^{\prime}, 7^{\prime}$-dichlorofluorescein assay. Cells were exposed to $50 \mu \mathrm{M}$ $2^{\prime}, 7^{\prime}$-dichlorofluorescein diacetate (DCFH-DA; Molecular Probes, Eugene, OR) for $30 \mathrm{~min}$. The cells were washed and exposed to serumfree media. After the specified incubation times, the cell-associated $2^{\prime}, 7^{\prime}$-dichlorofluorescein levels were analyzed by flow cytometry.

Other methods. Other methods used in this study have been described previously. ${ }^{1,2}$

Statistical analysis. Data are presented as the means \pm s.d. for at least three independent experiments. Where appropriate, statistical differences ere assessed by the Wilcoxon Mann-Whitney test. A $P$-value $<0.05$ was considered statistically significant.

\section{ACKNOWLEDGMENTS}

The funders had no role in the study design, data collection and analysis, decision to publish, or preparation of the manuscript.

\section{DISCLOSURE}

None of the authors have a financial relationship with a commercial entity that has an interest in the subject of this manuscript.

(C) 2012 Society for Mucosal Immunology

\section{REFERENCES}

1. Song, K.S., Kim, H.J. \& Lee, J.G. Rgulator of G-protein signaling 4 suppresses LPS-induced MUC5AC overproduction in the airway. Am. J. Respir. Cell Mol. Biol. 41, 40-49 (2009).

2. Song, K.S., Choi, Y.H., Kim, J.M., Lee, H., Lee, T.J. \& Yoon, J.H. Suppression of prostaglandin E2-induced MUC5AC overproduction by RGS4 in the airway. Am. J. Physiol. Lung Cell Mol. Physiol. 296, L684-L692 (2009).
3. Song, K.S., Kim, K., Chung, K.C., Seol, J.H. \& Yoon, J.H. Interaction of SOCS3 with NonO attenuates IL-1 beta-dependent MUC8 gene expression. Biochem. Biophys. Res. Commun. 377, 946-951 (2008).

4. Fujisawa, T., Velichko, S., Thai, P., Hung, L.Y., Huang, F. \& Wu, R. Regulation of airway MUC5AC expression by IL-1 beta and IL-17A; the NF-kappaB paradigm. J. Immunol. 183, 6236-6243 (2009).

5. Song, K.S. et al. Interleukin-1 beta and tumor necrosis factor-alpha induce MUC5AC overexpression through a mechanism involving ERK/p38 mitogen-activated protein kinases-MSK1-CREB activation in human airway epithelial cells. J. Biol. Chem. 278, 23243-23250 (2003).

6. Song, K.S. et al. Induction of MUC8 gene expression by interleukin-1 beta is mediated by a sequential ERK MAPK/RSK1/CREB cascade pathway in human airway epithelial cells. J. Biol. Chem. 278, 34890-34896 (2003).

7. Gerhauser, I., Alldinger, S. \& Baumgärtner, W. Ets-1 represents a pivotal transcription factor for viral clearance, inflammation, and demyelination in a mouse model of multiple sclerosis. J. Neuroimmunol. 188, 86-94 (2007).

8. Grenningloh, R., Kang, B.Y. \& Ho, I.C. Ets-1, a functional cofactor of Tbet, is essential for Th1 inflammatory responses. J. Exp. Med. 201, 615-626 (2005).

9. Song, K.S., Lee, T.J., Kim, K., Chung, K.C. \& Yoon, J.H. cAMPresponding element-binding protein and $\mathrm{c}$-Ets 1 interact in the regulation of ATP-dependent MUC5AC gene expression. J. Biol. Chem. 283, 26869-26878 (2008).

10. Li, R., Pei, H. \& Watson, D.K. Regulation of Ets function by protein-protein interactions. Oncogene 19, 6514-6523 (2000).

11. Oemar, B.S. Is interleukin-1 beta a triggering factor for restenosis? Cardiovasc. Res. 44, 17-19 (1999).

12. Kaur, J., Dhaunsi, G.S. \& Turner, R.B. Interleukin-1 and nitric oxide increase NADPH oxidase activity in human coronary artery smooth muscle cells. Med. Princ. Pract. 13, 26-29 (2004).

13. Griendling, K.K., Sorescu, D. \& Ushio-Fukai, M. NAD(P)H oxidase: role in cardiovascular biology and disease. Circ. Res. 86, 494-501 (2000).

14. Lambeth, J.D. NOX enzymes and the biology of reactive oxygen. Nat. Rev. Immunol. 4, 181-189 (2004).

15. Ago, T. et al. NOX4 as the major catalytic component of an endothelial NAD(P)H oxidase. Circulation 109, 227-233 (2004).

16. Ushio-Fukai, M. \& Nakamura, Y. Reactive oxygen species and angiogenesis: NADPH oxidase as target for cancer therapy. Cancer Lett. 266, 37-52 (2008).

17. Jayaraman, G., Srinivas, R., Duggan, C., Ferreira, E., Swaminathan, S. \& Somasundaram, K. et al. p300/cAMP-responsive element-binding protein interactions with ets- 1 and ets- 2 in the transcriptional activation of the human stromelysin promoter. J. Biol. Chem. 274, 17342-17352 (1999).

18. Yang, C., Shapiro, L.H., Rivera, M., Kumar, A. \& Brindle, P.K. A role for CREB binding protein and p300 transcriptional coactivators in Ets-1 transactivation functions. Mol. Cell Biol. 18, 2218-2229 (1998).

19. Foulds, C.E., Nelson, M.L., Blaszczak, A.G. \& Graves, B.J. Ras/mitogenactivated protein kinase signaling activates Ets- 1 and Ets-2 by CBP/p300 recruitment. Mol. Cell Biol. 24, 10954-10964 (2004).

20. Park, H. et al. A distinct lineage of CD4 T cells regulates tissue inflammation by producing interleukin 17. Nat. Immunol. 6, 1133-1141 (2005).

21. Russell, L. \& Garrett-Sinha, L.A. Transcription factor Ets-1 in cytokine and chemokine gene regulation. Cytokine 51, 217-226 (2010).

22. Chung, W.C., Ryu, S.H., Sun, H., Zeldin, D.C. \& Koo, J.S. CREB mediates prostaglandin F2alpha-induced MUC5AC overexpression. J. Immunol. 182, 2349-2356 (2009).

23. Kallapur, S.G. et al. IL-1 mediates pulmonary and systemic inflammatory responses to chorioamnionitis induced by lipopolysaccharide. Am. J. Respir. Crit. Care Med. 179, 955-961 (2009).

24. Wang, H. et al. Clara cell 10-kD protein suppresses chitinase 3-like 1 expression associated with eosinophilic chronic rhinosinusitis. Am. J. Respir. Crit. Care Med. 181, 908-916 (2010).

25. Ni, W., Zhan, Y., He, H., Maynard, E., Balschi, J.A. \& Oettgen, P. Ets-1 is a critical transcriptional regulator of reactive oxygen species and p47(phox) gene expression in response to angiotensin II. Circ. Res. 101, 985-994 (2007). 
26. Pearse, D.D., Tian, R.X., Nigro, J., lorgulescu, J.B., Puzis, L. \& Jaimes, E.A. Angiotensin II increases the expression of the transcription factor ETS-1 in mesangial cells. Am. J. Physiol. Renal Physiol. 294, F1094-F1100 (2008).

27. Xu, D. et al. Ets 1 is required for p53 transcriptional activity in UVinduced apoptosis in embryonic stem cells. EMBO J. 21, 4081-4093 (2002).

28. Nagarajan, P., Parikh, N., Garrett-Sinha, L.A. \& Sinha, S. Ets1 induces dysplastic changes when expressed in terminally-differentiating squamous epidermal cells. PLoS One 4, e4179 (2009).

29. Li, D., Gallup, M., Fan, N., Szymkowski, D.E. \& Basbaum, C.B. Cloning of the amino-terminal and $5^{\prime}$-flanking region of the human MUC5AC mucin gene and transcriptional up-regulation by bacterial exoproducts. J. Biol. Chem. 273, 6812-6820 (1998).

30. Moon, C., Lee, Y.J., Park, H.J., Chong, Y.H. \& Kang, J.L. $\mathrm{N}$-acetylcysteine inhibits RhoA and promotes apoptotic cell clearance during intense lung inflammation. Am. J. Respir. Crit. Care Med. 181, 374-387 (2010).

31. Kim, H.J. et al. The role of NOX4 in oxidative stress-induced MUC5AC overexpression in human airway epithelial cells. Am. J. Respir. Cell Mol. Biol. 39, 598-609 (2008).

32. Kim, H.J. et al. Crosstalk between platelet-derived growth factor-induced NOX4 activation and MUC8 gene overexpression in human airway epithelial cells. Free Radic. Biol. Med. 50, 1039-1052 (2011).
33. Lee, C.F., Qiao, M., Schröder, K., Zhao, Q. \& Asmis, R. NOX4 is a novel inducible source of reactive oxygen species in monocytes and macrophages and mediates oxidized low density lipoprotein-induced macrophage death. Circ. Res. 106, 1489-1497 (2010).

34. Yadav, U.C., Aguilera-Aguirre, L., Ramana, K.V., Boldogh, I. \& Srivastava, S.K. Aldose reductase inhibition prevents metaplasia of airway epithelial cells. PLoS One 28, e14440 (2010)

35. Severgnini, M. et al. Activation of the STAT pathway in acute lung injury. Am. J. Physiol. Lung Cell Mol. Physiol. 286, L1282-L1292 (2004).

36. Chen, Y., Zhao, Y.H. \& Wu, R. Differential regulation of airway mucin gene expression and mucin secretion by extracellular nucleotide triphosphates. Am. J. Respir. Cell Mol. Biol. 25, 409-417 (2001).

37. Salani, B. et al. Newborn liver gene transfer by an HIV-2-based lentiviral vector. Gene Ther. 12, 803-814 (2005).

38. Cheng, G. \& Lambeth, J.D. Alternative mRNA splice forms of NOXO1: differential tissue expression and regulation of NOX1 and NOX3. Gene $356,118-126$ (2005).

(c)

This work is licensed under the Creative Commons Attribution-NonCommercial-No Derivative Works 3.0

Unported License. To view a copy of this license, visit http://creativecommons.org/licenses/by-nc-nd/3.0/ 